\title{
Review
}

\section{Does the Consumption of Green Tea Reduce the Risk of Lung Cancer Among Smokers?}

\author{
Wenbin Liang, Colin W. Binns, Le Jian and Andy H. Lee \\ School of Public Health, Curtin University of Technology, Perth, Australia
}

\begin{abstract}
Experimental and epidemiological studies were reviewed to assess whether the consumption of green tea could reduce the risk of lung cancer in smokers. Articles published since 1990 were located by searching electronic databases PubMed, Ovid and Science Direct, using keywords 'lung cancer', 'tea' and 'smoking' without any restriction on language. After relevant articles had been located, further papers were obtained from their reference lists. Evidence from experimental studies (in vitro animal and human trials) suggested that regular intake of green tea may be protective against tobacco carcinogens. However, the mechanism behind the protective effect is only partly understood. In most of the epidemiological studies reviewed, the green tea exposure was within 5 years of the interview or followup, which would coincide with the induction period and latent period of lung cancer. Longer term studies are thus needed to further quantify the cancer risk. There is some evidence suggesting regular intake of green tea at high level ( $>3$ cups per day) may reduce the risk of smokers developing lung cancer. Improvement in measuring green tea intake is required in order to confirm the evidence from epidemiological studies.
\end{abstract}

Keywords: carcinoma - polyphenols - smoking - tobacco

\section{Introduction}

Lung cancer has become one of the leading causes of death in both developed and developing countries $(1,2)$. Most of the deaths from lung cancer are due to smoking tobacco products. Worldwide in 2000, tobacco smoking contributed $77 \%$ of the lung cancer deaths in males aged 30-69 years, and 82\% in males over 70 years $(1,2)$. In 2003 , for example, the prevalence of smoking in China was estimated to be $58.9 \%$ among adult males, while Chinese smokers are four times more likely to die from lung cancer than non-smokers (3).

Although elimination of tobacco smoke exposure is the obvious strategy to control lung cancer, no country has been completely successful in implementing an effective intervention. The efficacy of smoking cessation programs may be enhanced if they are conducted in conjunction with other complementary therapies. Epidemiological and experimental

For reprints and all correspondence: Professor Andy H. Lee, School of Public Health, Curtin University of Technology, GPO Box U1987, Perth, WA 6845, Australia. Tel: +61-8-92664180; Fax: +61-8-92662958;

E-mail: Andy.Lee@curtin.edu.au studies have suggested that green tea may be protective against cancer in different sites (4-21). In particular, recent evidence from in vitro, animal and human trial studies indicated the possibility that the consumption of green tea may reduce the risk of lung cancer among smokers $(2,22-$ 35 ), yet findings from epidemiological studies remained inconsistent.

The aim of this review is to assess evidence from experimental and epidemiological studies whether green tea is a risk modifier for those exposed to tobacco smoke. The focus is on the measurement of green tea exposure undertaken in these studies.

\section{Methods}

Articles published since 1990 were located by searching electronic databases PubMed, Ovid and Science Direct, using keywords 'lung cancer', 'tea' and 'smoking' without any restriction on language. After relevant articles had been located, further papers were obtained from their reference lists. A total of 78 relevant articles were eventually found. 


\section{Results and Discussion}

\section{In vitro and Animal Studies}

Both in vitro and animal studies have demonstrated that green tea or tea polyphenols have a chemopreventive effect against carcinogens from tobacco and is dependent on both the period and dose of the exposure.

\section{Period of exposure}

The period of exposure to green tea or tea polyphenols and the period of exposure to carcinogens must overlap. In one in vitro study, green tea polyphenols were introduced once into the living cell environment $2 \mathrm{~h}$ before exposing the cells to a smoke solution for $30 \mathrm{~min}$. Result showed that green tea polyphenols can reduce DNA strand breakage induced by cigarette smoke in cultured human bronchial cells A549 (32). In another in vitro study, human lymphoid cells were exposed to one single dose of green tea extracting solution $2 \mathrm{~h}$ before adding benzo $(a)$ pyrene-diol-epoxide (BPDE) - a metabolic production of benzo $(a)$ pyrene $(\mathrm{B}(a) \mathrm{P})$, which is a major component of tobacco. The results demonstrated that green tea can significantly reduce DNA damage caused by BPDE (22). Similarly in four other animal studies $(23,29,33,34)$, mice were given green tea prior to or within $48 \mathrm{~h}$ of exposure to tobacco carcinogens, and the green tea was continuously administered for 16 weeks or 9 months. Other experimental conditions such as diet, humidity, temperature and dark/light cycle were controlled. Three out of the four studies found a reduction in the incidence and the size of lung cancer tumors due to drinking green tea $(23,33,34)$.

\section{Dose of exposure}

The preventive effect of green tea is likely to be related to the concentration of green tea as well as the dose of carcinogens. In experimental studies both cells and animals were often treated with relatively high doses of carcinogens and green tea. For example, in a study which showed a protective effect of green tea, the concentration of tobacco carcinogens used was equivalent to the amount contained in the sidestream smoke from one cigarette dissolved in $24 \mathrm{ml}$ of water, while the concentration of green tea polyphenol was set at $250 \mu \mathrm{g} \mathrm{ml}^{-1}$, corresponding to $116.5 \mu \mathrm{g} \mathrm{ml}^{-1}$ of epigallocatechin-3-gallate (EGCG) (32). Moreover, the bioavailability of different green tea polyphenols has been a concern in animal and human studies. Green tea polyphenols are not usually stable, specifically, in water, EGCG can oxidize more than $50 \%$ within $12 \mathrm{~h}$, yet green tea used in experimental studies was typically prepared every $48 \mathrm{~h}(33,34)$ to every 7 days $(29)$.

In some studies where mice were exposed to both NNK [4(methylnitrosamino)-1-(3-pyridyl)-1-butanone] and green tea, the NNK dosage administered was usually equal to that experienced by a smoker in a lifetime (36). In one experiment mice were randomized into different groups and given green tea solution at concentrations of $0.2 \%, 0.4 \%$ and $0.6 \%$ as drinking fluid $24 \mathrm{~h}$ after treating with NNK. Comparing with the control group that drank only water, the protective effect of green tea was only evident at the $0.6 \%$ concentration level (33). In another study (29), mice were exposed to high levels of environmental tobacco smoke for 5 months, while being given $1.25 \%$ green tea $(2.5 \mathrm{~g}$ tea leave mixed with $200 \mathrm{ml}$ boiling water). The results indicated green tea had little effect on reducing tumor incidence or multiplicity of the tumors. However, none of the animals in the green tea treatment group experienced early death while $>10 \%$ of the mice in the control group experienced early deaths, probably due to an overdose of carcinogens exposure (29). Findings from these experiments suggest that green tea may not be effective to inhibit the formation or growth of lung tumor under high level of carcinogens exposure and over a long duration.

\section{Human Trials}

\section{Short-term effect}

Because a single dose of green tea intake only produces a short-term antioxidant effect, regular consumption seems necessary. In a human study (37), 21 non-smokers consumed $300 \mathrm{ml}$ of green tea solution or about three cups. Ferric reducing ability of plasma (FRAP-assay) was used to determine the antioxidant activity in plasma. The results of this study showed that green tea consumption produced a significant increase in antioxidant activity within 30-120 min of exposure, but after $120 \mathrm{~min}$ the antioxidant activity appeared to decrease. Another human trial with 10 healthy subjects similarly found a short-term increase of plasma antioxidant induced by drinking two to three cups of green tea at one time (38). Such a short-term increase seemed to correspond with the relatively short half-life of tea polyphenols (30). In one pharmacokinetic study (39), 30 healthy participants ingested $200 \mathrm{mg}$ of EGCG equivalent to two cups of green tea. Blood samples were collected at 0.5, 1, 2, 4, 6, 8 and $24 \mathrm{~h}$ after the EGCG administration. This experiment found that the mean half-life of EGCG in plasma was only $118 \mathrm{~min}$.

\section{Protective effect from regular consumption}

Regular green tea consumption could be protective over an extended period. In one pilot study (35), three non-smokers and three smokers (consumed more than 10 cigarettes per day) drank two cups of green tea in the morning, two cups in the afternoon and one cup at night daily for 4 weeks. Each cup of green tea contained $400-500 \mathrm{mg}$ of green tea extract. Oral keratinocytes were harvested from each subject for analysis. Outcomes included a reduction in smoking-induced DNA damage, increased apoptosis and a further decrease in the number of cells carrying damaged DNA (35). In a randomized control trial (27), 133 smokers who smoked at least 10 cigarettes per day during the past year were randomized into three groups consuming at least four cups daily of either (i) decaffeinated green tea, (ii) decaffeinated black tea, or 


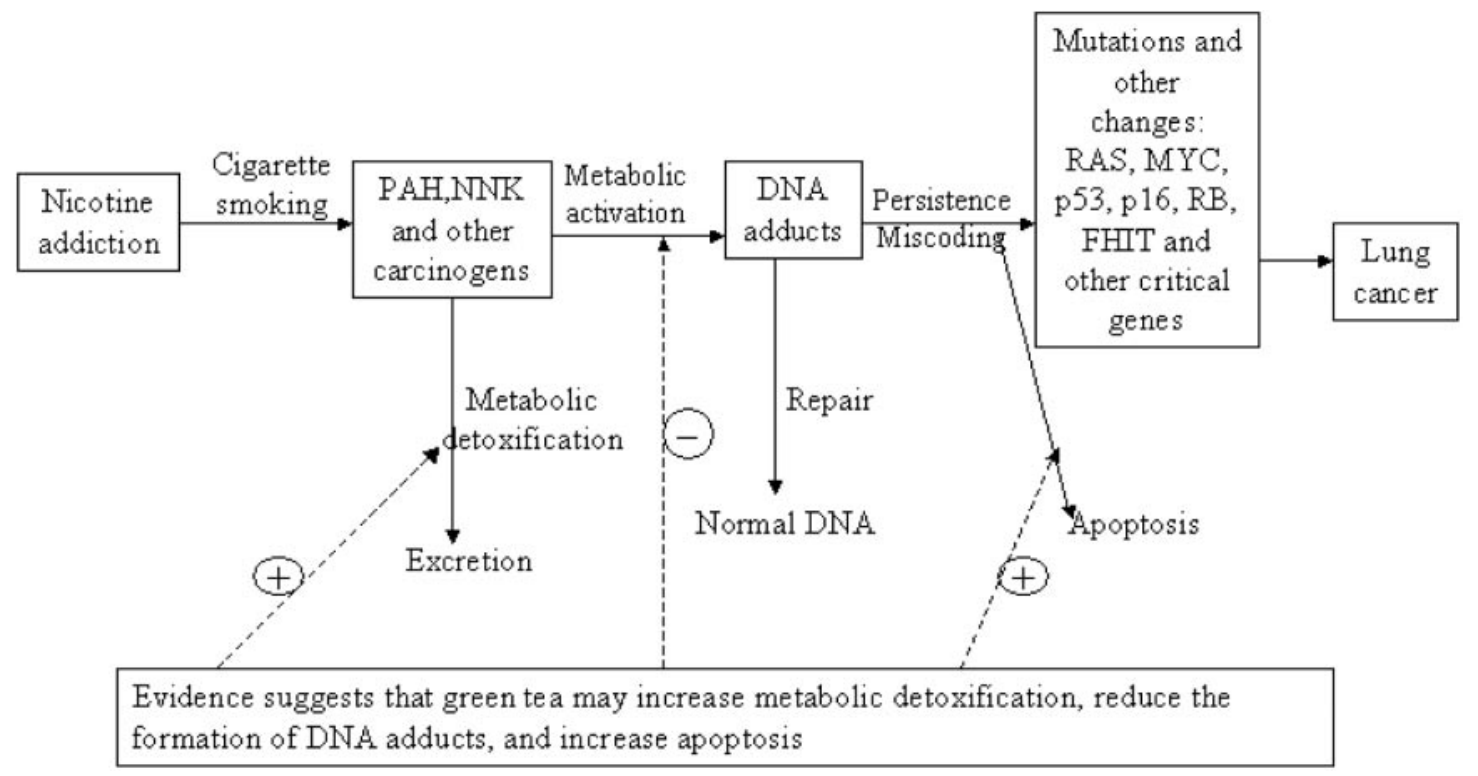

Figure 1. Mechanism of tobacco carcinogens inducing lung cancer.

(iii) water. After 4 months of intervention, smokers who drank decaffeinated green tea had a significant decrease in their urinary 8-hydroxydeoxyguanosine $(8-\mathrm{OHdG})$ level, but no significant changes were observed in both water and black tea groups. Similar reduction in urinary $8-\mathrm{OHdG}$ level was observed among HbsAg positive volunteers who took daily capsules containing green tea polyphenols equivalent to two to four cups of tea for 3 months (40). In an intensive observational study (25), the frequencies of sister-chromatid exchange (SCE) in peripheral lymphocytes were measured as markers of smoking-induced DNA damage. The frequencies of SCE were significantly higher among smokers who were nontea drinkers, than those of non-smokers and smokers who consumed green tea at least two to three cups per day during the past 6 months. The differences between the latter two groups, however, were not significant. It is possible that consuming high levels of green tea over a long period may reduce the DNA damage caused by tobacco smoking.

\section{Lung tumor treatment}

Only one clinical trial used green tea for treatment of lung cancer (41). In this Phase I study, 17 advanced lung cancer patients were given green tea extract at a single dose of $3 \mathrm{~g} \mathrm{~m}^{-2}$ per day for 4 weeks. The dosage equates to 20 cups of green tea, which has been found to be the maximum tolerated dose. Unfortunately, no effect of the treatment was observed. Therefore, green tea is unlikely to be an effective cytotoxic agent against existing tumor.

\section{Limitation of human trials}

Except two studies $(27,40)$, most human intervention studies involved small sample sizes generally less than 50 subjects. In addition to ethical concerns, there were neither direct measurement on the concentration of green tea polyphenols
Table 1. Possible mechanism of action

\begin{tabular}{ll}
\hline $\begin{array}{l}\text { Possible mechanism of chemoprevention } \\
\text { effect of green tea }\end{array}$ & References \\
\hline $\begin{array}{l}\text { Acting as antioxidant to prevent DNA } \\
\text { damage and reduce the formation } \\
\text { of DNA adducts }\end{array}$ & $(11,22,25,27,35,40)$ \\
$\begin{array}{l}\text { Increasing apoptosis and preventing the } \\
\text { persistence of miscoding DNA (possibly } \\
\text { by inducing gene regulation) }\end{array}$ & $(11,26,31,33,35,40,43,44)$ \\
$\begin{array}{l}\text { Activating Phase II detoxifying enzymes, } \\
\text { and increasing the excretion of carcinogens } \\
\text { (possibly by inducing gene regulation) }\end{array}$ & $(2,8,28,31)$ \\
\hline
\end{tabular}

in lung tissue nor on the change of lung tissue after green tea exposure. Instead, the effects of green tea were measured by the change in DNA damage and apoptosis of oral cells (35), changes in biomarkers of DNA damage such as $8-\mathrm{OHdG}$ and SCE $(25,27,40)$, and changes in plasma antioxidant capacity $(30,37,38)$. Trials with sufficient sample size and longer period of follow-up are needed to confirm the protective effect of green tea.

\section{Mechanisms Based on Experimental Studies}

As shown in Fig. 1, carcinogens contained in cigarette smoke are activated by Phase I enzymes in the body, leading to the formation of DNA adducts (36). If DNA adducts escape cellular repair mechanisms, it may result in miscoding and eventually a stable mutation. Blocking any step in the pathway would reduce the incidence of lung cancer among smokers (36). Table 1 provides the possible mechanisms of chemoprevention effect of green tea. The evidence suggested that catechins in green tea, especially EGCG, may prevent the formation of a mutated cell.

In both animal and in vitro studies, green tea was found to increase the activities of Phase II enzymes $(2,8,28,31)$. Phase II 
Table 2. Epidemiology studies on tea and lung cancer

\begin{tabular}{|c|c|c|c|c|c|c|}
\hline Country & Study design & Sample size & $\begin{array}{l}\text { Tea type and highest } \\
\text { consumption level }\end{array}$ & $\begin{array}{l}\text { Reference period } \\
\text { of intake }\end{array}$ & $\begin{array}{l}\text { Smoking status } \\
\text { of subjects }\end{array}$ & Results \\
\hline China (50) & $\begin{array}{l}\text { Population-based } \\
\text { case-control study }\end{array}$ & $\begin{array}{l}\text { Cases: } 649 \\
\text { Controls: } 675\end{array}$ & $\begin{array}{l}\text { Green tea: }>1500 \mathrm{~g} \\
\text { tea leaves per year }\end{array}$ & 5 years before interview & $\begin{array}{l}\text { Smokers and } \\
\text { non-smokers }\end{array}$ & $\begin{array}{l}\mathrm{OR}=0.65 ; 95 \% \\
\mathrm{CI}=0.45-0.93 \text { for } \\
\text { non-smokers } \\
\mathrm{OR}=0.94 ; \\
95 \% \mathrm{CI}=0.40-2.22 \\
\text { for smokers }\end{array}$ \\
\hline Canada (52) & $\begin{array}{l}\text { Population-based } \\
\text { case-control study }\end{array}$ & $\begin{array}{l}\text { Cases: } 582 \\
\text { Controls: } 582\end{array}$ & $\begin{array}{l}\text { Type unspecified: } \\
>7 \text { cups per day }\end{array}$ & 2 years before study & Non-smokers & $\begin{array}{l}\mathrm{OR}=0.4 ; 95 \% \\
\mathrm{CI}=02-0.7\end{array}$ \\
\hline USA (51) & $\begin{array}{l}\text { Population based } \\
\text { case-control study }\end{array}$ & $\begin{array}{l}\text { Cases: } 161 \\
\text { Controls } 483\end{array}$ & $\begin{array}{l}\text { Green tea: } \\
>1 \text { cup per day }\end{array}$ & $\begin{array}{l}1 \text { year before diagnosis } \\
\text { or interview }\end{array}$ & $\begin{array}{l}\text { Smokers and } \\
\text { non-smokers }\end{array}$ & $\begin{array}{l}\mathrm{OR}=0.9 ; 95 \% \\
\mathrm{CI}=0.5-1.6\end{array}$ \\
\hline Japan (53) & $\begin{array}{l}\text { Cohort study } \\
(1980-94)\end{array}$ & $\begin{array}{l}\text { Subjects: } 38540 \\
\text { Person-years at risk: } \\
\text { unspecified } \\
\text { Cases: } 436\end{array}$ & $\begin{array}{l}\text { Green tea: } \\
>5 \text { times per day }\end{array}$ & $\begin{array}{l}\text { Unspecified; survey taken } \\
\text { at start of study }\end{array}$ & $\begin{array}{l}\text { Smokers and } \\
\text { non-smokers }\end{array}$ & $\begin{array}{l}\mathrm{RR}=0.78 ; 95 \% \\
\mathrm{CI}=0.6-1.0 \text { for } \\
\text { people drinking tea } \\
2-4 \text { times per day }\end{array}$ \\
\hline Japan (54) & $\begin{array}{l}\text { Cohort study } \\
(1986-95)\end{array}$ & $\begin{array}{l}\text { Subjects: } 8552 \\
\text { Person-years at } \\
\text { risk: } 71248.5 \\
\text { Cases: } 384\end{array}$ & $\begin{array}{l}\text { Green tea: } \\
>10 \text { cups per day }\end{array}$ & $\begin{array}{l}\text { Unspecified; survey taken at } \\
\text { start of study }\end{array}$ & $\begin{array}{l}\text { Smokers and } \\
\text { non-smokers }\end{array}$ & $\begin{array}{l}\text { Cancer in all sites } \\
\mathrm{RR}=0.68 \text { for males; } \\
95 \% \mathrm{CI}=0.39-1.21 \\
\mathrm{RR}=0.57 \text { for females; } \\
95 \% \mathrm{CI}=0.33-0.98\end{array}$ \\
\hline
\end{tabular}

OR, odds ratio; $\mathrm{RR}$, relative risk; $\mathrm{CI}$, confidence interval.

enzymes transform carcinogens into non-toxic molecules for subsequent excretion (42). The amount of carcinogens that may be further activated, as well as DNA adducts, are thus reduced. The antioxidant properties of green tea have also been demonstrated in trials involving smokers. It reduced the urine concentration of 8-OHdG, a strong biomarker of DNA damage (27). Moreover, green tea extract could inhibit the formation of human DNA adducts $(11,22,35)$.

Once carcinogen DNA adducts have formed, persistent mutation is likely unless cells with DNA adducts are removed by apoptosis (36). Human (35), animal $(11,33)$ and in vitro studies $(26,43,44)$ have shown that green tea can induce apoptosis among injured cells exposed to carcinogens from tobacco smoke. However, smoking may be regarded as a chronic exposure, since long duration of tobacco smoking has greater impact on lung caner risk than the amount smoked per day (45). Therefore, a long exposure to green tea is needed in order to reduce the damage caused by tobacco carcinogens.

\section{Epidemiological Studies}

\section{Induction time and latent period of lung carcinoma}

Latent period refers to the time between disease occurrence and detection, while tumor induction time commences when the effect of the exposure occurs until all of the component causes involved in one sufficient cause are satisfied-the time of disease occurrence (46). Exposure within the induction and latent periods is irrelevant to the formation of a tumor (47). Moreover, the incidence of lung cancer does not appear to be lower among ex-smokers who quit smoking within 5 years than current smokers $(48,49)$. This indicates that the sum of induction period and latent period of lung cancer caused by tobacco smoking may be longer than 5 years. Logically, no reduction in incidence of lung carcinoma is expected among current smokers who drink green tea for 5 years prior to the calculation of incidence, regardless of their consumption level.

\section{Measurement of green tea exposure and other limitations}

Table 2 summarizes epidemiological studies on tea and lung cancer. Three case-control studies (50-52) found a significantly lower risk of lung cancer among non-smokers with a high consumption of green or black tea, but no protective effect was evident among smokers $(50,51)$. However, the period of tea consumption referred to 5 years or less before the diagnosis or interview. Although the subjects might have been drinking tea for a long time, the duration and quantity of tea consumption was not assessed, so the effect of green tea could not be fully justified. Cohort studies, on the other hand, were based on information of tea consumption at the beginning of the study (53-55) and suggested that tea consumption increased with age $(54,55)$. In particular, the Japanese study (53) with a long follow-up period of 14 years showed that people consuming green tea two to four times per day had a relative risk of $0.78(95 \% \mathrm{CI}=0.6-1.0)$, when compared with those drinking once or less per day and after adjustment for potential confounders. But for subjects drinking green tea more than five times per day, the relative risk was only $0.79(95 \% \mathrm{CI}=0.59-1.1)$, the non-significance result probably due to insufficient sample size at this high level of consumption (53).

In summary, there is only limited evidence from epidemiological studies that green tea is protective against lung cancer among smokers. Moreover, green tea exposure was generally taken to be within 5 years of interview or follow-up, which would have little impact on the incidence of lung cancer. 


\section{Conclusion}

Our review suggests that regular intake of green tea at high levels ( $>3$ cups per day) may offer protection against tobacco carcinogens for smokers, provided that the duration of green tea consumption is sufficiently long to cover the smoking period. For epidemiology studies, improvement in measuring green tea intake is required in order to confirm the chemopreventive effect of green tea observed in in vitro animal and human trials.

\section{References}

1. Ezzati M, Lopez AD. Estimates of global mortality attributable to smoking in 2000. Lancet 2003;362:847-52.

2. Yu R, Jiao JJ, Duh JL, Gudehithlu K, Tan TH, Kong AN. Activation of mitogen-activated protein kinases by green tea polyphenols: potential signaling pathways in the regulation of antioxidant-responsive elementmediated phase II enzyme gene expression. Carcinogenesis 1997;18: 451-6.

3. Lam TH, Ho SY, Hedley AJ, Mak KH, Peto R. Mortality and smoking in Hong Kong: case-control study of all adult deaths in 1998. Br Med J 2001;323:361.

4. Wu X, Gu J, Amos CI, Jiang H, Hong WK, Spitz MR. A parallel study of in vitro sensitivity to benzo[a]pyrene diol epoxide and bleomycin in lung carcinoma cases and controls. Cancer 1998;83:1118-27.

5. Su LJ, Arab L. Tea consumption and the reduced risk of colon cancerresults from a national prospective cohort study. Public Health Nutr 2002;5:419-25.

6. Katiyar SK, Agarwal R, Zaim MT, Mukhtar H. Protection against $N$ nitrosodiethylamine and benzo[a]pyrene-induced forestomach and lung tumorigenesis in A/J mice by green tea. Carcinogenesis 1993;14:849-55.

7. Fujiki H, Suganuma M, Okabe S, Sueoka N, Komori A, Sueoka E, et al. Cancer inhibition by green tea. Mutat Res 1998;402:307-10.

8. Katiyar SK, Mukhtar H. Tea antioxidants in cancer chemoprevention. $J$ Cell Biochem Suppl 1997;27:59-67.

9. Kohlmeier L, Weterings KG, Steck S, Kok FJ. Tea and cancer prevention: an evaluation of the epidemiologic literature. Nutr Cancer 1997;27:1-13.

10. Gensler HL, Timmermann BN, Valcic S, Wachter GA, Dorr R, Dvorakova K, et al. Prevention of photocarcinogenesis by topical administration of pure epigallocatechin gallate isolated from green tea. Nutr Cancer 1996;26:325-35.

11. Chung FL, Schwartz J, Herzog CR, Yang YM. Tea and cancer prevention: studies in animals and humans. J Nutr 2003;133:3268S-74S.

12. Crespy V, Williamson G. A review of the health effects of green tea catechins in in vivo animal models. J Nutr 2004;134(12 Suppl): $3431 \mathrm{~S}-40 \mathrm{~S}$.

13. Jian L, Xie LP, Lee AH, Binns CW. Protective effect of green tea against prostate cancer: a case-control study in southeast China. Int J Cancer 2004;108:130-5.

14. Lee AH, Fraser ML, Meng X, Binns CW. Protective effects of green tea against prostate cancer. Expert Rev Anticancer Ther 2006;6: $507-13$.

15. Lee AH, Fraser ML, Binns CW. Possible role for green tea in ovarian cancer prevention. Future Oncol 2005;1:771-7.

16. Zhang M, Lee AH, Binns CW, Xie X. Green tea consumption enhances survival of epithelial ovarian cancer. Int J Cancer 2004;112:465-9.

17. Binns CW, Zhang M, Lee AH, Xie CX. Green tea consumption enhances survival of epithelial ovarian cancer patients. Asia Pac J Clin Nutr 2004;13(Suppl):S116.

18. Galanis DJ, Kolonel LN, Lee J, Nomura A. Intakes of selected foods and beverages and the incidence of gastric cancer among the Japanese residents of Hawaii: a prospective study. Int J Epidemiol 1998;27:173-80.

19. Hoshiyama Y, Kawaguchi T, Miura Y, Mizoue T, Tokui N, Yatsuya H, et al. A prospective study of stomach cancer death in relation to green tea consumption in Japan. Br J Cancer 2002;87:309-13.

20. Sasazuki $S$, Inoue $M$, Hanaoka $T$, Yamamoto $S$, Sobue $T$, Tsugane $S$. Green tea consumption and subsequent risk of gastric cancer by subsite: the JPHC Study. Cancer Causes Control 2004;15:483-91.

21. Ravindranath MH, Saravanan TS, Monteclaro CC, Presser N, Ye X, Selvan SR, et al. Epicatechins purified from green tea (Camellia sinensis) differentially suppress growth of gender-dependent human cancer cell lines. Evid Based Complement Alternat Med 2006;3:237-47.

22. Zhang H, Spitz MR, Tomlinson GE, Schabath MB, Minna JD, Wu X. Modification of lung cancer susceptibility by green tea extract as measured by the comet assay. Cancer Detect Prev 2002;26:411-8.

23. Chung FL. The prevention of lung cancer induced by a tobacco-specific carcinogen in rodents by green and black Tea. Proc Soc Exp Biol Med 1999;220:244-8.

24. Okabe S, Suganuma M, Hayashi M, Sueoka E, Komori A, Fujiki H. Mechanisms of growth inhibition of human lung cancer cell line, PC-9, by tea polyphenols. Jpn J Cancer Res 1997;88:639-43.

25. Lee IP, Kim YH, Kang MH, Roberts C, Shim JS, Roh JK. Chemopreventive effect of green tea (Camellia sinensis) against cigarette smokeinduced mutations (SCE) in humans. J Cell Biochem Suppl 1997;27: $68-75$.

26. Yang GY, Liao J, Li C, Chung J, Yurkow EJ, Ho CT, et al. Effect of black and green tea polyphenols on c-jun phosphorylation and $\mathrm{H}(2) \mathrm{O}(2)$ production in transformed and non-transformed human bronchial cell lines: possible mechanisms of cell growth inhibition and apoptosis induction. Carcinogenesis 2000;21:2035-9.

27. Hakim IA, Harris RB, Brown S, Chow HH, Wiseman S, Agarwal S, et al. Effect of increased tea consumption on oxidative DNA damage among smokers: a randomized controlled study. J Nutr 2003;133:3303S-9S.

28. Khan SG, Katiyar SK, Agarwal R, Mukhtar H. Enhancement of antioxidant and phase II enzymes by oral feeding of green tea polyphenols in drinking water to SKH-1 hairless mice: possible role in cancer chemoprevention. Cancer Res 1992;52:4050-2.

29. Witschi H, Espiritu I, Yu M, Willits NH. The effects of phenethyl isothiocyanate, $N$-acetylcysteine and green tea on tobacco smoke-induced lung tumors in strain A/J mice. Carcinogenesis 1998;19:1789-94.

30. Young JF, Dragstedt LO, Haraldsdottir J, Daneshvar B, Kal MA, Loft S, et al. Green tea extract only affects markers of oxidative status postprandially: lasting antioxidant effect of flavonoid-free diet. $\mathrm{Br} J$ Nutr 2002;87:343-55.

31. Ahmad N, Mukhtar H. Green tea polyphenols and cancer: biologic mechanisms and practical implications. Nutr Rev 1999;57:78-83.

32. Leanderson P, Faresjo AO, Tagesson C. Green tea polyphenols inhibit oxidant-induced DNA strand breakage in cultured lung cells. Free Radic Biol Med 1997;23:235-42.

33. Liao J, Yang GY, Park ES, Meng X, Sun Y, Jia D, et al. Inhibition of lung carcinogenesis and effects on angiogenesis and apoptosis in A/J mice by oral administration of green tea. Nutr Cancer 2004;48:44-53.

34. Landau JM, Wang ZY, Yang GY, Ding W, Yang CS. Inhibition of spontaneous formation of lung tumors and rhabdomyosarcomas in $\mathrm{A} / \mathrm{J}$ mice by black and green tea. Carcinogenesis 1998;19:501-7.

35. Schwartz JL, Baker V, Larios E, Chung FL. Molecular and cellular effects of green tea on oral cells of smokers: a pilot study. Mol Nutr Food Res 2005;49:43-51.

36. Hecht SS. Tobacco smoke carcinogens and lung cancer. J Natl Cancer Inst 1999;91:1194-210.

37. Leenen R, Roodenburg AJ, Tijburg LB, Wiseman SA. A single dose of tea with or without milk increases plasma antioxidant activity in humans. Eur J Clin Nutr 2000;54:87-92.

38. Sung H, Nah J, Chun S, Park H, Yang SE, Min WK. In vivo antioxidant effect of green tea. Eur J Clin Nutr 2000;54:527-9.

39. Chow HH, Cai Y, Alberts DS, Hakim I, Dorr R, Shahi F, et al. Phase I pharmacokinetic study of tea polyphenols following single-dose administration of epigallocatechin gallate and polyphenon E. Cancer Epidemiol Biomarkers Prev 2001;10:53-8.

40. Luo H, Tang L, Tang M, Billam M, Huang T, Yu J, et al. Phase IIa chemoprevention trial of green tea polyphenols in high-risk individuals of liver cancer: modulation of urinary excretion of green tea polyphenols and 8-hydroxydeoxyguanosine. Carcinogenesis 2006;27:262-8.

41. Laurie SA, Miller VA, Grant SC, Kris MG, Ng KK. Phase I study of green tea extract in patients with advanced lung cancer. Cancer Chemother Pharmacol 2005;55:33-8.

42. Guengerich FP. Metabolism of chemical carcinogens. Carcinogenesis 2000;21:345-51.

43. Yang CS, Chung JY, Yang G, Chhabra SK, Lee MJ. Tea and tea polyphenols in cancer prevention. J Nutr 2000;130(2S Suppl):472S-8S.

44. Suganuma M, Kurusu M, Suzuki K, Tasaki E, Fujiki H. Green tea polyphenol stimulates cancer preventive effects of celecoxib in human lung cancer cells by upregulation of GADD153 gene. Int $J$ Cancer 2006;119:33-40. 
45. Alberg AJ, Samet JM. Epidemiology of lung cancer. Chest 2003;123(1 Suppl):21S-49S.

46. Rothman J, Greenland S. Modern Epidemiology. Philadelphia: LippincottRaven, 1998.

47. Savitz DA. Interpreting epidemiologic evidence: strategies for study design and analysis. New York: Oxford University Press, 2003.

48. Wakai K, Seki N, Tamakoshi A, Kondo T, Nishino Y, Ito Y, et al Decrease in risk of lung cancer death in males after smoking cessation by age at quitting: findings from the JACC study. Jpn J Cancer Res 2001;92: 821-8.

49. Pohlabeln H, Jockel KH, Muller KM. The relation between various histological types of lung cancer and the number of years since cessation of smoking. Lung Cancer 1997;18:223-9.

50. Zhong L, Goldberg MS, Gao YT, Hanley JA, Parent ME, Jin F. A population-based case-control study of lung cancer and green tea consumption among women living in Shanghai, China. Epidemiology 2001;12:695-700.
51. Le Marchand L, Murphy SP, Hankin JH, Wilkens LR, Kolonel LN. Intake of flavonoids and lung cancer. J Natl Cancer Inst 2000;92: $154-60$.

52. Hu J, Mao Y, Dryer D, White K. Risk factors for lung cancer among Canadian women who have never smoked. Cancer Detect Prev 2002;26: $129-38$.

53. Nagano J, Kono S, Preston DL, Mabuchi K. A prospective study of green tea consumption and cancer incidence, Hiroshima and Nagasaki (Japan). Cancer Causes Control 2001;12:501-8.

54. Imai K, Suga K, Nakachi K. Cancer-preventive effects of drinking green tea among a Japanese population. Prev Med 1997;26: $769-75$.

55. Goldbohm RA, Hertog MG, Brants HA, van Poppel G, van den Brandt PA. Consumption of black tea and cancer risk: a prospective cohort study. $J$ Natl Cancer Inst 1996;88:93-100.

Received November 23, 2005; accepted August 25, 2006 


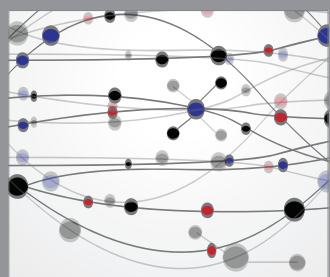

The Scientific World Journal
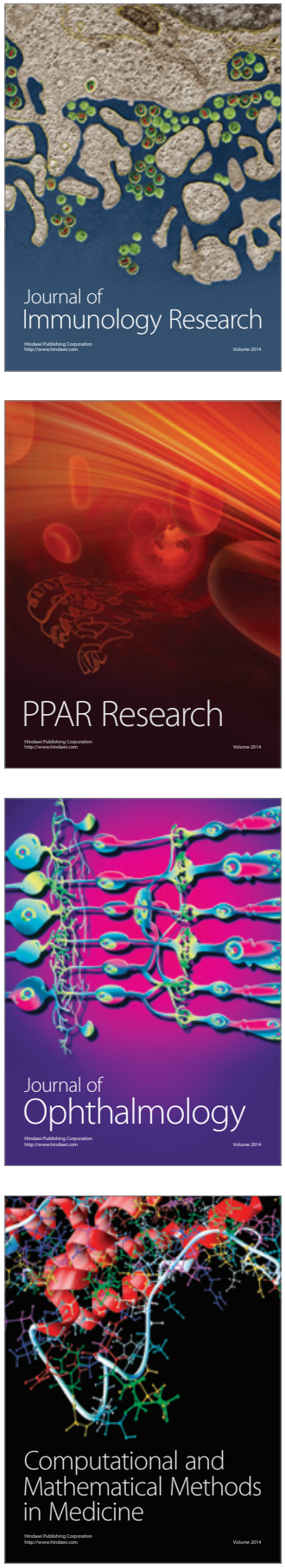

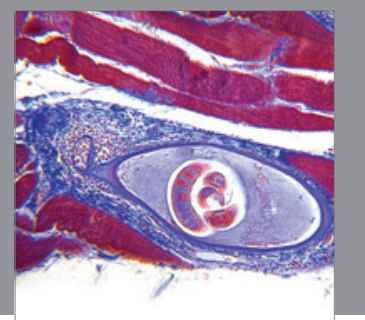

Gastroenterology

Research and Practice
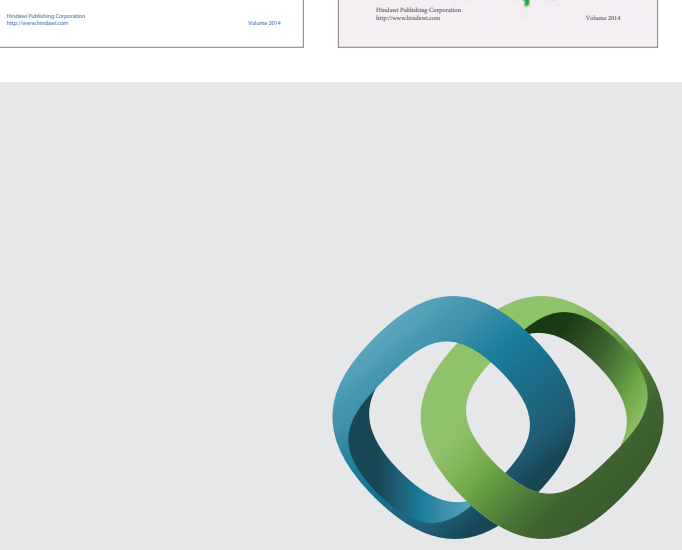

\section{Hindawi}

Submit your manuscripts at

http://www.hindawi.com
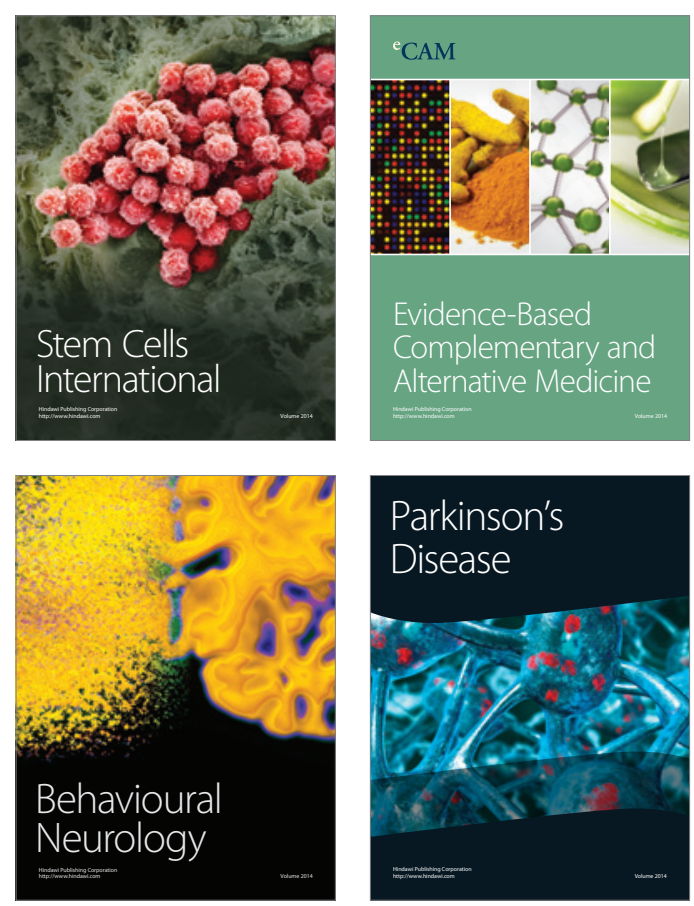

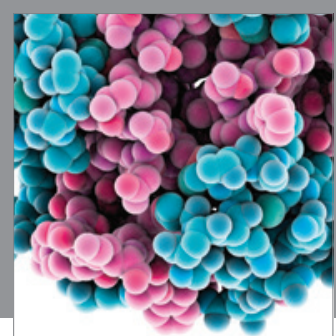

Journal of
Diabetes Research

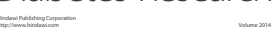

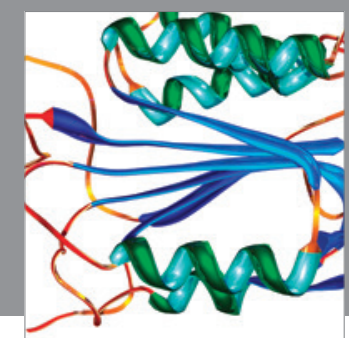

Disease Markers
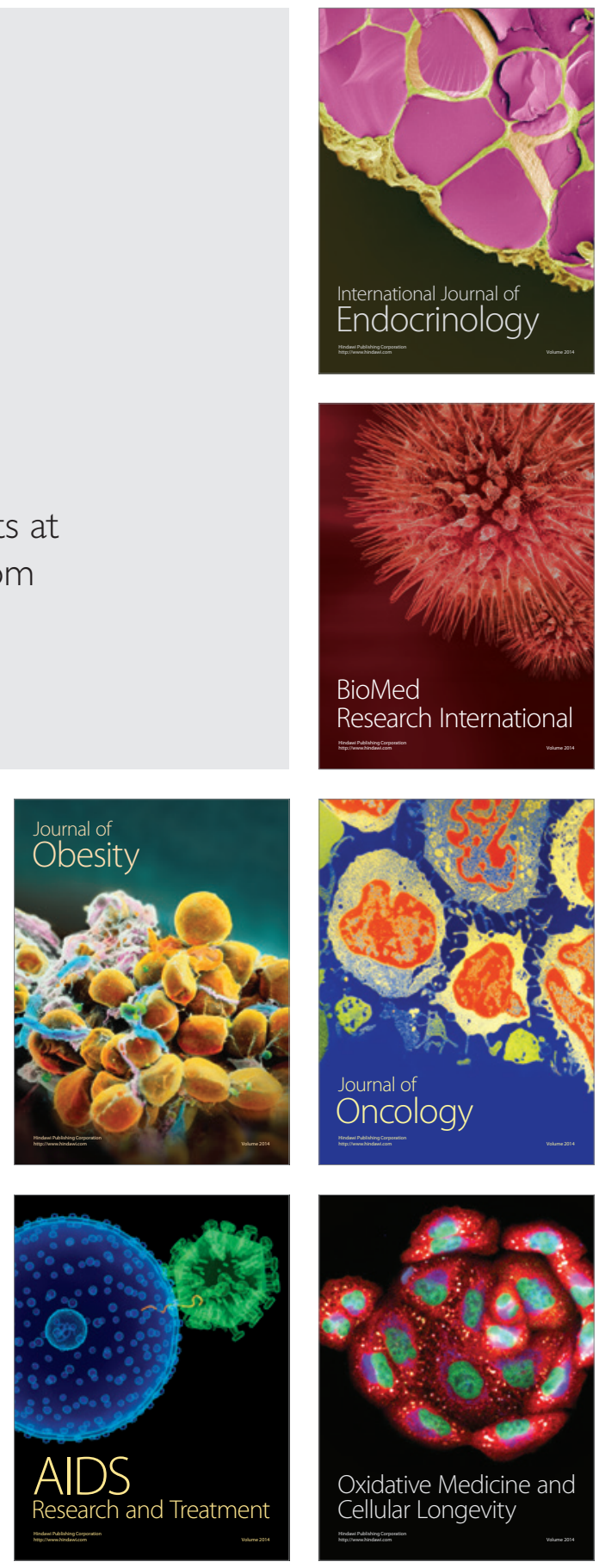